\title{
THAILAND 4.0'S INNOVATION AND TECHNOLOGY: ANALYZING INDICATOR LEVEL
}

\author{
Pisit Potjanajaruwit
}

Suan Sunandha Rajabhat University, Bangkok, Thailand

\begin{abstract}
The objective of the research titled'Innovation and Technology of Small and Medium Enterprises (SMEs) in Coconut Sugar Business in Thailand 4.0' is to study the level of innovation and technology of Small and Medium Enterprises (SMEs) in the coconut sugar business in Samut Songkhram Province. This research is the Mixed Methods Research and the populations of this research consisted of entrepreneurs and executives as well as those who engage in the development of innovation and technology of Small and Medium Enterprises (SMEs) in the coconut sugar business in Samut Songkhram Province.The results showed that SMEs' innovation and technology consisted of 3 components including Innovation and Technology in Learning, Innovation and Technology in Communication and Innovation and Technology in Operational Support. Innovation and Technology in Communication was ranked as No. 1with the highest Mean, it was found that there are 3 areas of innovation and technology to be studied, including Innovation and Technology in Learning, Innovation and Technology in Communication and Innovation and Technology in Operational Support. Based on the data analysis for the rating scale on the innovation and technology, it was found that the rating scale on communication was ranked as No. 1 with the highest Mean $(\bar{x}=.440 S . D$. $=.043)$, No. 2 was the innovation and technology in learning with the highest Mean ( $\bar{x}=4.38$ S.D. $=$ 0.44 ) and No. 3 was the innovation and technology on operational support with the highest Mean ( $\bar{x}=$ 33.4S.D. $=.047)$. All variables are statistically significant influences.
\end{abstract}

Keywords: Innovation and technology; Thailand 4.0 Policy; Leadership Style; SMEs

\section{Introduction}

SMEs play an important role as a mechanism to drive the economy of many countries, similar to many Thai SMEs that are small businesses and also help to absorb the unemployed labor of the agricultural sector after the harvest season. Based on the data from the Office of Small and Medium Enterprises Promotion (OSMEP), Thailand's 2013 GDP is worth of 4.5 Trillion Baht or $37.4 \%$ of GDP, which is not much change from $37.8 \%$ in 2009 , causing a question whether we would have a way to promote the business of SMEs to be more expanded.

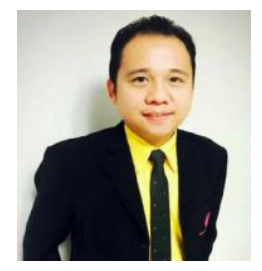

Pisit Potjanajaruwit

Doctor of Business Administration (Marketing) in Sripatum University, Bangkok, Thailand

Assistant Dean for International Affairs, Faculty of Management Science,

Suan Sunandha Rajabhat University, Thailand

Research interests: integrated marketing communication, branding strategy, service marketing for Sufficiency Economy

E-mail: pisit.po@ssru.ac.th 


\section{THAILAND 4.0'S INNOVATION AND TECHNOLOGY}

This article, therefore, wishes to present ideas to SMEs to realize the importance and tendency of technology application in SMEs' business operations for more effective management, cost reduction and market expansion as well as the guidelines encouraging SMEs to use technology for business expansion (Chittithaworn et al., 2011).

The results from OSMEP's research prepared in 2017 showed that the importance of SMEs to the economy in terms of the ratio of the number of entrepreneurs per entrepreneurs, SMEs play an important role as a mechanism to drive the economy of many countries, similar to many Thai SMEs that are small businesses which help to absorb the unemployed labors of the agricultural sector after the harvest season for more than $90 \%$ in total among countries to be studied including Thailand, Singapore, Malaysia, Philippines, Indonesia and Vietnam.

As well, the proportion of Gross Domestic Product of SMEs in GDP is accounted for approximately a quarter in Indonesia and a half in Singapore. In terms of applying innovations, it was found that Thai SMEs that have brought new innovations to help in business operations are still low by obtaining3.6 points from 10 full points, less than Singapore (8.7 points) and Malaysia (4.4 points), reflecting that Thai SMEs' competitiveness will be decreased if they do not adjust themselves. However, if looking at the Internet usage index of SMEs in ASEAN countries, it is seen that it is very high and Thai SMEs still have a slightly lower proportion of internet usage than other countries in the region at $87 \%$, which may reflect the Internet efficiency and the ability to access the internet that is not covered in many areas whereas Singapore and Indonesia's ratios are 97\% and 96\%, respectively (Limthongchai \& Speece, 2003).

While the proportion of Thai SMEs' business on the internet is higher than other countries in the ASEAN region, at 34\%, followed by Philippines (29\%) and Malaysia (24\%), implying that Thai SMEs have the great potential to develop business on the internet, this responds the result of survey on the status of Thailand's electronic commerce in 2014, prepared by the National Statistical Office and the Ministry of Information and Communication Technology, it was found that (see Fig.) in 2013, the sales of e-commerce businesses via electronic commerce was worth 7.7 Billion Baht, expanding almost double from sales in 2007.

If analyzing from Thailand's electronic commerce data during 2007-2013, it was found that approximately $50 \%$ of the procurement value was by bidding method via the public sector's internet network and 35\% was a trade between entrepreneurs (B2B - Business to Business) covering the wholesale, ordering through electronic system, supply chain management system, etc., whereas $4 \%$ was a trade between consumers and consumers (C2C Consumer to Consumer), such as exchanging goods among themselves, selling second-hand products, etc.

Under the digital economy policy, the government sector and various organizations jointly encourage SMEs to apply technology in developing their businesses for more production efficiency and the added value to products and services as well as being a channel to link transactions of those involved in both consumers, entrepreneurs and government sector because the electronic transactions or e-commerce are convenient and can be used with communication devices, either Smartphone or Tablet (Sutanonpaiboon \& Pearson, 2006).

From the results of survey on the opinions of industrial entrepreneurs, organized by the

Bank of Thailand, the Northeastern Office, in the $2^{\text {nd }}$ quarter of 2015, it was found that SMEs 
have applied the technology in business for 3 main areas including Learning, Communication and Operational Support.At present, the innovation and technology are smaller and cheaper, enabling businesses to buy machinery with new technology from Europe that has high efficiency at a price that is almost half cheaper, to produce construction materials, many businesses decided to buy new machines to replace labor shortages as a way to adjust their businesses for survival.Their products are also developed with new innovations by cooperating with government agencies.

Therefore, based on the importance and origin of the above problems, it led to the research titled "Innovation and Technology of Small and Medium Enterprises (SMEs) in Coconut Sugar Business in Thailand 4.0 with the focus to obtain concrete and useful knowledge to promote the development of SMEs' competitiveness for the coconut sugar business in Thailand 4.0. The objective of the research is as follows: to study the level of innovation and technology of Small and Medium Enterprises (SMEs) in coconut sugar business in Samut Songkhram Province.

\section{Literature Review}

\section{SMEs's Innovation and Technology}

Based on the literature review on SMEs Innovation and Technology from the research articles and academic articles, it was found that (Lane y al., 2019) explained that SMEs Innovation and Technology is a significant factor for all SMEs both small and medium size.The results of the study showed that the innovation and technology have resulted in the growth of the business and being the business competitiveness factor.

If considering the resources of the organizations that are successful with the innovation and technology on learning, the innovation and technology on communication and the innovation and technology on the operational support, it was found that the factor of innovation and technology depended upon the skills and expertise of each organization.From the study, it was found that the sustainability and stability of the business start from establishing the appropriate strategy in terms of IT (Information Technology), which is extremely required and considered as the basis of the current business strategy. In addition, the innovation also adds the value and increases the performance to the organization.

The evidence of the connection between innovation \& technology and SMEs' business competitiveness was clearly shown in the results of the study conducted by (Pucihar et al., 2019) that was found that the organization's ability to use the innovation and technology on learning, on communication has resulted in more productivity than competitors within the same industry that do not highly invest on the innovation and technology.

The results of this study also additionally suggested that the innovation and technology can make the organization more competitive in terms of cost leadership due to the lower production costs; and can make its products and services different as well.

However, based on the literature review from existing academic articles on the relation between the innovation \& technology and the increase of competitiveness, none of academicians explains this topic. Most academicians have mentioned that the efficiency of innovation and technology will help the business to adapt itself to the business environment very well and can improve the manufacturing process of products and services to be more efficient. 


\section{THAILAND 4.0’S INNOVATION AND TECHNOLOGY}

However, the innovation and technology also contribute to the organization's ability to compete with the advantage of cost leadership and differentiation after that the business invests in IT resources such as computer hardware's, programs on IT personnel (Oncioiu et al., 2018).

In the past, Small and Medium Enterprises (SMEs) who have more investment in the innovation and technology than competitors, have received more return on investment than businesses that invested a small amount in the innovation and technology. However, none of empirical study can prove that the creation of sustainability for a business is only driven by the innovation and technology consisting of the technology on corporate people's learning, technology on communication and technology on the operational support technology until (Valdez-Juarez et al., 2018) presented their study results that could prove this important issue.

It was found that the potential for the innovation and technology on learning, on internal and external communications, innovation on operational support that affects the competitiveness of the business in terms of cost reduction, differentiation and responding to specific group satisfaction in businesses that significantly offer products and services, especially the innovation on communication that help to effectively flow the data within the organization or business, as shown in the Tab.1 showing the measurement of the variables of innovation and technology that affect the competitiveness of Small and Medium Enterprises (SMEs), which is consistent with (Adane, 2018) that defines the term 'SMEs' Innovation and Technology' that it is the change and improvement of the existing environment within the organization, such improvement must be consistent with the condition of the technology at that time, together with the accumulation of knowledge, experience and expertise of personnel, whether it be the innovation and technology on learning, on communication, as well as on the operational support, leading to new values or new things to be presented to consumers, where as explained that the National Economic and Social Development Plan of each country focuses on the establishment of both small-sized and medium-sized businesses by putting effort in encouraging those businesses to drive and emphasize their application of innovation and technology in order to increase their ability on learning, on internal and external communication as well as using technology to support the operations for the increase of business capabilities.

Based on the literature review relating to measurement of variables on the innovation and technology of coconut sugar business from research articles and academic articles, it was found that (Chesbrough, 2003) conducting the research for the development of SMEs in order to efficiently develop new products and services in the Netherlands.

It explained that SMEs in the Netherlands increase their efficiency in operations to expand their businesses with the commitment and development in R\&D and was found that the technology and innovation can enhance the learning of personnel in the organization very well, whether it be the use of Could Technology, the use of Search Engine to search for information for consideration and decision, the use of technology and information on communication, these technologies can reduce the operational costs and make products and services differentiated very well.

Additionally, it was also found that the use of commercial technology also covers the stimulation of customers's demands and can increase the cash flow for businesses very well, for example, Online Exhibition, E-market, etc. The corporate leaders and the government's policy to support and promote ICT will mostly be the important driving forces in developing 
the corporate technology and innovation to be more varieties and responsive to customers' satisfactions in the new era with efficiency.

This corresponds to (Kirschbaum, 2005), explaining that at present, the use of technology and innovation to improve the operational efficiency in order to increase business capabilities has received more attention from entrepreneurs, although the investment in the initial stage of system improvement is high and in the in-depth interview, entrepreneurs also found that the application of technology and innovation is not limited in terms of the size of the organization and the inequality of resources in each organization due to the software in some types of operations is Open Source, which the developer gives for free of charge and some applied software's can also be applied in a variety of industries and respond to many missions of the organization, whether it be software to support the learning or the work of people in the organization, such as E-market Place, the application of I-could technology to store information and share information, the use of Social Media in marketing, the use of Line application, etc.

It was found that such technology and innovation will help to reduce the cost and create the competitiveness to the business very well and followed in same direction as (Sanchez Gutierrez et al., 2018) that studied the innovations affecting the operational efficiency of Small and Medium-sized Businesses in Germany, Switzerland and Austria because these countries was facing the problem that the big-scaled business expanded their business at a rate that so fast to affect Small and Medium Enterprises (SMEs) and then they had to find a solution for this problem due to SMEs' limited resources and money in capital investment.

It was found that technology and innovation can reduce the gap between large business and small business very well due to the application of business technology, whether it be the increase of knowledge and creativity for people in the organization to invent products and services that are different from competitors in the same industry and also enable businesses to meet the satisfaction of particular customer group because the E-market Place technology can offer more specialized information.

\section{Research Methodology}

Based on the conceptual framework from the literature review of the research titled 'Innovation and Technology of Small and Medium Enterprises (SMEs) in Coconut Sugar Business in Thailand 4.0', the research applied the Mixed Methods consisting of Qualitative Research and Quantitative Research, to acquire the findings that meet the objectives, in this chapter, the researcher would like to present various issues related to the research methodology as follows:

\section{Procedures to establish the conceptual framework for research}

In this research, the researcher has an important objective that the research results will be beneficial to the society as a whole, in academic and professional areas in relation to the innovation and technology of Small and Medium Enterprises (SMEs) in coconut sugar business in Thailand 4.0. The research will study about the factors, causes and effects of the innovation and technology affecting the competitiveness of the coconut sugar business in Thailand 4.0 to confirm the conceptual framework. The data will be collected from 3 Key Informants who are executives or those responsible for regulating and involving in the 


\section{THAILAND 4.0’S INNOVATION AND TECHNOLOGY}

creation of innovation and technology of Small and Medium Enterprises (SMEs) in coconut sugar business, by applying the Purposive Sampling method of Tongco, M. (2007).

\section{Procedures to create research tools}

After the researcher studied the first part with the executive or those responsible for supervision and involving in determining the innovation and technology that affects the competitiveness by using the in-depth interview method to collect data from the key informants and using the Purposive Sampling method which is the Qualitative Research to study the factors, causes and results of the innovation and technology affecting the competitiveness, this data will be applied to create the Quantitative Questionnaire.

In creating the research tools, the researcher conducted the study, the literature review, concept, relevant theories to set the operational definition and structure of variables to be studied. The researcher then created the questions according to the operational definition, developed the measurement tools and questions that had been tested and improved to be suitable for the research, the researcher presented the improved questions to experts on the innovation and technology affecting the competitiveness of Small and Medium Enterprises (SMEs) in coconut sugar business.

Table 1 - Measurement methods and data sources for developing the questions by researcher

\begin{tabular}{|c|c|c|c|c|}
\hline Variables & Measurement method & Measurement & No. of Questions & $\begin{array}{c}\text { Data Sources for } \\
\text { developing the } \\
\text { questions by researcher }\end{array}$ \\
\hline $\begin{array}{c}\text { Innovation } \\
\text { and } \\
\text { Technology }\end{array}$ & $\begin{array}{c}5=\text { The highest rating scale } \\
4=\text { High rating scale } \\
\begin{array}{c}3=\text { Medium rating scale } \\
2=\text { Low rating scale } \\
1=\text { The lowest rating scale }\end{array}\end{array}$ & Interval & 15 questions & (Pucihar et al., 2019) \\
\hline
\end{tabular}

\section{Sampling techniques and sample size}

The representative samples used in this research were randomly taken by the researcher using Cluster Random Sampling, from the distributed populations, causing difficulty to establish the framework of populations, or from the natural aggregated populations (according to geography. Despite its overall characteristic similarity, complete differences or diversity can be observed within each group to enable decrease in error on estimation of parameter value of populations under Probability Sampling.

After that, the calculation based on the formula (Allen, 2003) was applied to determine the size of the representative sample group with exact number of populations, concluding at 395representative samples. The data is collected by questionnaires that were delivered and attached to the request letter, self introduction letter, explanation on how to fill in questionnaires and the envelop with returning address and affixed postal stamp, this corresponded with the explanation of Dillman D. A. (2000). 
Table 2 - Representative Samples classified by Small and Medium enterprises (SMEs) that manufacture coconut sugar, Bang Khonthi District, Samut Songkhram Province (Source: Office of Small and Medium Enterprises Promotion, 2018)

\begin{tabular}{|l|c|c|c|}
\hline $\begin{array}{c}\text { Small and Medium Enterprises (SMEs) that } \\
\text { Manufacture Coconut Sugar in Bang Khonthi } \\
\text { District, Samut Songkhram Province, under Sub- } \\
\text { district Area Classification }\end{array}$ & $\begin{array}{c}\text { No. of } \\
\text { Populations }\end{array}$ & $\begin{array}{c}\text { No. of } \\
\text { Representative } \\
\text { Samples }\end{array}$ & Percentage \\
\hline 1. Kradangnga & 5,688 & 67.88 & 17.18 \\
\hline 2. Bang Sakae & 2,070 & 24.70 & 6.25 \\
\hline 3. Bang Yi Rong & 1,932 & 23.05 & 5.83 \\
\hline 4. Rong Hip & 2,192 & 26.15 & 6.62 \\
\hline 5. Bang Khonthi & 2,393 & 28.55 & 7.22 \\
\hline 6. Don Manora & 4,200 & 50.10 & 12.68 \\
\hline 7. Bang Phrom & 2,826 & 33.72 & 8.53 \\
\hline 8. Bang Kung & 1,636 & 19.52 & 4.94 \\
\hline 9. Chom Pluak & 3,377 & 40.30 & 10.20 \\
\hline 10.Bang Nok Khwaek & 1,366 & 16.42 & 4.15 \\
\hline 11. Yai Phaeng & 1,553 & 18.67 & 4.72 \\
\hline 12. Bang Krabue & 1,962 & 23.41 & 5.92 \\
\hline 13. Ban Pramot & 1,903 & 22.88 & 5.79 \\
\hline Total & 33,098 & 395 & 100 \\
\hline
\end{tabular}

\section{Analysis by Descriptive Statistics}

The Descriptive Statistics was applied to explain and describe the properties or characteristics of the distribution of variables according to the characteristics of the group, the outcomes of measurement were set as Percentage, Mean and Standard Deviation, and 12 observed variables of the basic statistics were analyzed to explain and describe the distribution of observed variables and the measurement values were Mean and Standard Deviation, to study the level of innovation and technology of Coconut Sugar Small and Medium Enterprises (SMEs) in Samut Songkhram Province. All Means were interpreted by the principal of Class Interval, applying the assessment criterio of (Hozo et al., 2005) as follows:
Mean between 4.21-5.00
Mean between 3.41-4.20
means Agreed the Most
Mean between 2.61-3.40
means Very Agreed
Mean between 1.81-2.60
means Moderately Agreed
Mean between 1.00-1.80
means Less Agreed
means Least Agreement

\section{Analysis/Study}

From the analysis, it was found that there are 3 areas of Innovation and technology to be studied, such as Innovation and technology on leaning, on communication and on operational support. Based on data analysis on the rating scale in terms of Innovation and technology, it was found that the rating scale on communication was ranked as No. 1 by the respondents with the highest Mean $(\overline{\mathrm{x}}=.440$ S.D. $=.043)$ and the opinions on communication from the list of questions can be sorted as follows: 


\section{THAILAND 4.0’S INNOVATION AND TECHNOLOGY}

1. Your business uses online communication channels such as Line, messenger and Email to effectively communicate both inside and outside the organization. $(\bar{x}=4.61$ SD $=$ $0.63)$; followed by

2. Your business use the Social Media to exchange opinions and respond to customers' needs $(\overline{\mathrm{x}}=4.56 \mathrm{SD}=0.62)$; and

3. Your business conducts activities of online retailing - whole selling (E-Commerce) $(\overline{\mathrm{x}}=4.46$ S.D. $=0.65)$.

Table 3 - Innovations and technologies of analyzed Sugar Coconut SMEs - 1

(Source: made by author)

\begin{tabular}{|l|c|c|c|c|}
\hline Innovation and technology & \multicolumn{3}{|c|}{ Rating scale } & \\
\cline { 2 - 5 } & $\bar{X}$ & $S . D$. & Interpretation & Ranking \\
\hline Communication: & 4.40 & 0.43 & Highest & 1 \\
\hline $\begin{array}{l}\text { 1. Your business uses online communication channels such as } \\
\text { Line, messenger and E-mail to effectively communicate both } \\
\text { inside and outside the organization. }\end{array}$ & 4.61 & 0.63 & Highest & \\
\hline $\begin{array}{l}\text { 2. Your business use the Social Media to exchange opinions } \\
\text { and respond to customers' needs. }\end{array}$ & 4.56 & 0.62 & Highest & \\
$\begin{array}{l}\text { 3. Your business conducts activities of online retailing - whole } \\
\text { selling (E-Commerce) }\end{array}$ & 4.46 & 0.65 & Highest & \\
\hline
\end{tabular}

Based on the data analysis, the rating scale about innovation and technology on learning was ranked as No. 2 , with the highest Mean ( $\bar{x}=4.38$ S.D. $=0.44)$, the opinions on the learning innovation can be sorted from the list of questions as follows:

1. The business uses the internet technology to help in seeking for knowledge, transferring knowledge and abilities that can enable personnel in the organization to invent products and services $(\overline{\mathrm{x}}=4.69$ S.D. $=0.53)$;

2. The business applies the online training to train employees for additional working knowledge $(\overline{\mathrm{x}}=4.33$ S.D. $=0.67)$; and

3. The business use the Computer Tablet as IT devices to allow employees to use for studying more working information. $(\overline{\mathrm{x}}=4.31$ S.D. $=0.72)$.

Table 4 - Innovations and technologies of analyzed Sugar Coconut SMEs - 2 (Source: made by author)

\begin{tabular}{|l|c|c|c|c|}
\hline Innovation and technology & \multicolumn{3}{|c|}{ Rating scale } & \\
\cline { 2 - 5 } & $\bar{X}$ & $S . D$. & Interpretation & Ranking \\
\hline Learning: & 4.38 & 0.44 & Highest & 2 \\
\hline $\begin{array}{l}\text { 1. The business uses the internet technology to help in seeking } \\
\text { for knowledge, transferring knowledge and abilities that can } \\
\text { enable personnel in the organization to invent products and } \\
\text { services }\end{array}$ & & 0.53 & Highest & \\
\hline $\begin{array}{l}\text { 2. The business applies the online training to train employees } \\
\text { for addditional working knowledge }\end{array}$ & 4.33 & 0.67 & \multicolumn{2}{|c|}{ Highest } \\
$\begin{array}{l}\text { 3. The business use the Computer Tablet as IT device to allow } \\
\text { employees to use for studying more working information. }\end{array}$ & & 0.32 & Highest & \\
\hline
\end{tabular}


Based on the data analysis, the rating scale about innovation and technology on operational support was ranked as 3, with the highest Mean $(\overline{\mathrm{x}}=4.33$ S.D. $=0.47)$, the opinions on the operational support innovation can be sorted from the list of questions as follows:

1. Your business applies the smartphone technology for payment, services and other service (Mobile Payment) to increase the convenience for customers ( $\bar{x}=4.55$ S.D. $=0.64)$;

2. Your business submits documents and pays taxes via the tax and electronic transaction document system $(\mathrm{E}-\mathrm{Tax})$ that helps to reduce the coordination cost $(\overline{\mathrm{x}}=4.30 \mathrm{SD}=0.66)$; and

3. Your business stores documents and information in the form of electronic data for the reduction of operational costs $(\overline{\mathrm{x}}=4.27 \mathrm{SD}=0.77)$.

Table 5 - Innovations and technologies of analyzed Sugar Coconut SMEs - 3

(Source: made by author)

\begin{tabular}{|l|c|c|c|c|}
\hline Innovation and technology & \multicolumn{3}{|c|}{ Rating scale } & \\
\cline { 2 - 5 } & $\bar{X}$ & $S . D$. & Interpretation & Ranking \\
\hline Operational Support & 4.33 & 0.47 & Highest & 3 \\
\hline $\begin{array}{l}\text { 1. Your business submits documents and pays taxes via the tax } \\
\text { and electronic transaction document system (E-Tax) that helps } \\
\text { to reduce the coordination cost }\end{array}$ & 4.55 & 0.64 & Highest & \\
\hline $\begin{array}{l}\text { 2. Your business uses the online data storage service (Cloud } \\
\text { Solutions) to effectively reduce the cost of data storage. }\end{array}$ & 4.30 & 0.67 & Highest & \\
$\begin{array}{l}\text { 3. Your business stores documents and information in the form } \\
\text { of electronic data for the reduction of operational costs }\end{array}$ & 4.27 & 0.77 & Highest & \\
\hline
\end{tabular}

\section{Discussion}

The analysis found that there were 3 areas of the Innovation and technology to be studied, namely Innovation and technology on Learning, on Communication and on Operational support, the analysis on the rating scale regarding the Innovation and technology found that the rating scale on Communication was ranked as 1 with the Mean at the highest level, meaning your business uses the online communication channels such as Line, messenger and E-mail, to effectively communicate inside and outside the organization, as well as you business uses the Social Media to exchange opinions with customers and respond customers' needs, the business also has the activities of online retailing - whole selling (ECommerce) by applying the method of payment for goods and services via QR Code system that can meet all the needs of customers.

Additionally, the business also has the VDO Conference (allowing distant or inconvenient employees to be able to listen to the meeting information as well as those in the company) with the highest Mean, this corresponds with (Valdez-Juarez et al., 2018) explaining that in the past, Small and Medium Enterprises (SMEs) that have invested in the innovation and technology more than competitors have received more return on investment than businesses that have invested a small amount in the innovation and technology.

However, none of empirical study can prove that the creation of sustainability for a business is only driven by the innovation and technology consisting of the technology on corporate people's learning, technology on communication and technology on the operational 


\section{THAILAND 4.0'S INNOVATION AND TECHNOLOGY}

support until (Pucihar et al., 2019), presented their study results that could prove this important issue.

It was found that the potential for the innovation and technology on learning, on internal and external communications, innovation on operational support that affects the competitiveness of the business in terms of cost reduction, differentiation and responding to specific group satisfaction in businesses that significantly offer products and services, especially the innovation on communication that help to effectively flow the data within the organization or business, as shown in the Tab. 3-5.

\section{Conclusions}

Based on the data on the rating scale regarding the innovation and technology, it found that the rating scale on Communication was ranked as 1 with the Mean at the highest level.Therefore, executives or those involved in innovation and technology of SMEs should focus on the activities or training for employees related to the use of online communication channels for the communication inside and outside the organization, the use of Social Media to exchange opinions with customers and respond to customers' needs, activities of online retailing - whole selling (E-Commerce), the method of payments for goods and services via QR Code system that can meet all the needs of customers and the operational efficiency is also increased with the VDO Conference, allowing distant or inconvenient employees to be able to listen to the meeting information as well as those in the company, etc.

\section{References:}

Adane, M. (2018). Cloud computing adoption: Strategies for Sub-Saharan Africa SMEs for enhancing competitiveness. African Journal of Science, Technology, Innovation and Development, 10(2): 197-207.

Allen, T. (2003). Powder sampling and particle size determination. Elsevier.

Chittithaworn, C., Islam, M. A., Keawchana, T., \& Yusuf, D. H. M. (2011). Factors affecting business success of small \& medium enterprises (SMEs) in Thailand. Asian Social Science, 7(5): 180-190.

Chesbrough, H. (2003). The logic of open innovation: managing intellectual property. California management review, 33-58.

Dillman, D. A. (2000). The Influence of Alternative Visual Designs on Respondent's performance with Branching Instructions in Self-administered Questionnaires. US Bureau of the Census.

Hozo, S. P., Djulbegovic, B., \& Hozo, I. (2005). Estimating the mean and variance from the median, range, and the size of a sample. Research methodology, 5(1): 13.

Kirschbaum, R. (2005). Open innovation in practice. Research-Technology Management, 48(4): 2428.

Limthongchai, P., \& Speece, M. (2003). The effect of perceived characteristics of innovation on ecommerce adoption by SMEs in Thailand. In Proceedings of the Seventh International Conference on Global Business and Economic Development, Bangkok, Thailand.

Lan, J., Chengjun, W., \& Wei, Z. (2019). Investigation of the evaluation system of SMEs' industrial cluster management performance based on wireless network development. EURASIP Journal on Wireless Communications and Networking, 1,1.

Oncioiu, I., Ifrim, A. M., Petrescu, A. G., \& Bilcan, F. R. (2018). Role of Green Innovation and Business Performance: Evidence from Romanian SMEs. Electrotehnica, Electronica, Automatica, 66(2): 129-134. 
Pucihar, A., Lenart, G., Kljajić Borštnar, M., Vidmar, D., \& Marolt, M. (2019). Drivers and Outcomes of Business Model Innovation-Micro, Small and Medium-Sized Enterprises Perspective. Sustainability, 11(2): 344.

Sánchez-Gutiérrez, J., Cabanelas, P., Lampón, J. F., \& González-Alvarado, T. E. (2018). The impact on competitiveness of customer value creation through relationship capabilities and marketing innovation. Journal of Business \& Industrial Marketing, 4.

Sutanonpaiboon, J., \& Pearson, A. M. (2006). E-commerce adoption: perceptions of managers/owners of small-and medium-sized enterprises (SMEs) in Thailand. Journal of Internet Commerce, 5(3): 53-82.

Tongco, M. D. C. (2007). Purposive sampling as a tool for informant selection. Ethnobotany Research and applications, 5: 147-158.

Valdez-Juárez, L. E., García-Pérez-de-Lema, D., \& Maldonado-Guzmán, G. (2018). ICT and KM, Drivers of Innovation and Profitability in SMEs. Journal of Information \& Knowledge Management, 17(01).

Paper submitted

Paper accepted for publishing

Paper published online
11 December 2018

24 January 2019

31 March 2019 